Vol. 8 (1999): 29-44.

\title{
Effects of cattle slurry and cultivation on air exchange in sandy and silty soils from northern Norway
}

Trond Knapp Haraldsen

Planteforsk, The Norwegian Crop Research Institute, Holt Research Centre, N-9292 Troms $\phi$, Norway Current address: Jordforsk, Centre for Soil and Environmental Research, N-1432 Ås, Norway,

e-mail: trond.haraldsen@jordforsk.nlh.no

\begin{abstract}
Gas diffusivity and permeability, and air-filled porosity, were measured in undisturbed soil cores at four water potentials between $-1.5 \mathrm{kPa}$ and $-60 \mathrm{kPa}$. Virgin (never ploughed) and cultivated sandy and silty soils from two sites in northern Norway were used in the investigation. The cultivated soils had lower air-filled porosity and gas diffusivity than the virgin ones. Application of slurry $\left(50 \mathrm{Mg} \mathrm{ha}^{-1}\right)$ decreased gas diffusivity and changed the relationship between relative diffusivity and air-filled porosity for both the virgin and cultivated sandy soils and the virgin silty soil. The gas permeability of both the virgin and cultivated silty soil was low, and the relative diffusivity at field capacity less than the limit below which plant growth is affected.
\end{abstract}

Keywords: aeration, cattle slurry, cultivation, gas diffusivity, permeability, porosity

\section{Introduction}

The use of liquid slurry on grassland is common in most districts in western and northern Norway. The effective mineral nitrogen in applied slurry is much less than equal amounts of $\mathrm{N}$ in inorganic NPK fertilizer (Håland 1988). Loss of $\mathrm{N}$ from surface applied slurry by ammonia volatilization can be one reason for the decreased fertilizing effect (Van der Meer et al. 1987). Sward damage caused by surface spreading, which concerns smothering, scorching and possibly other unknown effects, often results in a decrease of herbage yield (Prins and Snijders 1987). Slurry application to grassland may restrict soil aeration and cause evolution of methane, ethane, ethylene and propane. Anaerobiosis caused by slurry application may also cause denitrification in the soil. However, only a few studies on the effect of slurry on soil aeration have been carried out. In studies with very high applications of slurry on grassland (Stevens and Cornforth 1974, Burford 1976, Egginton and Smith 1986) evolution of methane and ethane, and increased $\mathrm{O}_{2}$ demand have been found. In the study of Labuda et al. (1976) slurry $\left(100 \mathrm{Mg} \mathrm{ha}^{-1}\right)$ mixed in the plough layer caused 


\section{Haraldsen, T.K. Effects of cattle slurry and cultivation on air exchange}

decrease in $\mathrm{O}_{2}$ content after application, but did lead to development of anaerobic conditions in the cultivated soil.

Soil compaction by heavy tankers during slurry application is a serious problem and reduces the water infiltration rate (Myhr et al. 1990), and reduces grass yield and nitrogen utilization (Douglas and Crawford 1998). Hansen and Bakken (1993) studied the effect of soil compaction during slurry application in leys on soil aeration. They found that compacted soil had lower $\mathrm{O}_{2}$ concentrations and higher $\mathrm{CO}_{2}$ concentrations than uncompacted soil. Concentrations of $\mathrm{O}_{2}$ and $\mathrm{CO}_{2}$ in the soil air were not influenced by fertilizer applications (unfertilized, NPK, and slurry).

Only a few papers concerning soil compaction and soil aeration in undisturbed soil have been published (Ball 1981, Ball 1987, Ball et al. 1988, McAfee et al. 1989, Rolston et al. 1991). Based on field experiments Ball (1987) concluded that relative diffusivities may be used to identify the water potential and bulk density at which aeration may limit plant growth. Moldrup et al. $(1997,1999)$ have developed models for predicting gas diffusion in undisturbed soils with high accuracy. Gas diffusion was predicted from airfilled porosity, and the introduction of a tortuousity parameter and measurements of gas permeability or gas diffusion at a defined water potential between -10 and $-50 \mathrm{kPa}$ improved the accuracy.

Cultivation of some soils for grass production in northern Norway has caused problems with winter damage and poor yields. Some farmers reported increased problems after application of cattle slurry, and it was proposed that the use of aerated slurry would be beneficial compared to fresh slurry. In order to identify if the problems were related to the slurry application or the physical properties of the soils, virgin (uncultivated, never ploughed) and cultivated soils of the same origin were studied. In this paper the effects of cultivation and surface spreading of cattle slurry (fresh and aerated slurry) on air exchange were studied in soils from northern Norway. Paired virgin and cultivated sandy and silty soils were used to assess the effects of anthropomorphic activity on air exchange. Undisturbed soil cores from these soils were used in laboratory experiments. Relative diffusivities were chosen in order to measure the effects of slurry and cultivation on soil aeration. Soils from the same locations have been used in previous studies of the influence of cultivation and slurry application on infiltration (Haraldsen and Sveistrup 1994), and the effect of slurry application on the microstructure of the surface layers of the soils (Sveistrup et al. 1995).

\section{Material and methods}

\section{Material}

Soils from two locations in northern Norway were used; a sand (Typic Cryaquent (Soil Survey Staff 1975), Dystric Arenic Regosol (FAO 1998)) from Pasvik $\left(69^{\circ} \mathrm{N}, 30^{\circ} \mathrm{E}\right)$, and a silt loam (Dystric Cryochrept (Soil Survey Staff 1975), Dystric Cambisol (FAO 1998)) from Tana $\left(70^{\circ} \mathrm{N}\right.$, $\left.27^{\circ} \mathrm{E}\right)$. Soil physical characteristics and organic carbon contents are presented in Table 1. Sveistrup (1992) gives a complete description of the soils. The climate at both sites is characterised as subarctic continental. The mean annual air temperature is $-1.1^{\circ} \mathrm{C}$ at Pasvik and $-0.7^{\circ} \mathrm{C}$ at Tana (Rustefjelmba). The mean temperature during summer (June-August) is $11.8^{\circ} \mathrm{C}$ at Pasvik and $10.5^{\circ} \mathrm{C}$ at Tana (Aune 1993). The growing seasons (temperatures above $6^{\circ} \mathrm{C}$ ) for the two sites are 124 days and 118 days, respectively.

The Tana location was chosen because it often shows restricted plant growth caused by soil compaction during cultivation, and winter damage caused by ponding and ice-cover (Lorentzen 1984). The virgin soil supported birch forest (Betula pubescens) with grasses and mosses. A thin mor humus layer covered the soil. The cultivated soil has been ploughed periodically since the 1920's, and the present sward age was seven years. The vegetation cover consisted mostly of 
Vol. 8 (1999): 29-44.

Table 1. Physical properties of the soils (according to Sveistrup, 1992).

\begin{tabular}{|c|c|c|c|c|c|c|c|}
\hline \multirow{2}{*}{$\begin{array}{l}\text { Depth, } \\
\mathrm{cm}\end{array}$} & \multicolumn{3}{|c|}{$\begin{array}{l}\text { Particle size distribution, } \\
\qquad{\mathrm{g} 100 \mathrm{~g}^{-1}}\end{array}$} & \multirow{2}{*}{$\begin{array}{c}\begin{array}{c}\text { Bulk } \\
\text { density, }\end{array} \\
\mathrm{Mg} \mathrm{m}^{-3}\end{array}$} & \multirow{2}{*}{$\begin{array}{c}\begin{array}{c}\text { Total } \\
\text { porosity, }\end{array} \\
\mathrm{m}^{3} \mathrm{~m}^{-3}\end{array}$} & \multirow{2}{*}{$\begin{array}{c}\begin{array}{c}\text { Air-filled } \\
\text { porosity, }\end{array} \\
\mathrm{m}^{3} \mathrm{~m}^{-3}\end{array}$} & \multirow{2}{*}{$\begin{array}{c}\begin{array}{c}\text { Organic } \\
\text { carbon, }\end{array} \\
\text { g } 100 \mathrm{~g}^{-1}\end{array}$} \\
\hline & $\begin{array}{c}\text { Sand, } \\
2-0.06 \\
\text { mm }\end{array}$ & $\begin{array}{c}\text { Silt, } \\
0.06- \\
0.002 \mathrm{~mm}\end{array}$ & $\begin{array}{c}\text { Clay, } \\
<0.002 \\
\text { mm }\end{array}$ & & & & \\
\hline \multicolumn{8}{|c|}{ Pasvik, sandy virgin } \\
\hline $0-14$ & 90 & 8 & 2 & 1.47 & 0.47 & 0.37 & 0.5 \\
\hline $14-36$ & 96 & 4 & 0 & 1.53 & 0.46 & 0.41 & 0.3 \\
\hline \multicolumn{8}{|c|}{ Pasvik, sandy cultivated } \\
\hline $0-7$ & 81 & 15 & 4 & - & - & - & 3.1 \\
\hline $7-21$ & 94 & 5 & 1 & 1.44 & 0.47 & 0.25 & 1.1 \\
\hline $21-44$ & 96 & 3 & 1 & 1.50 & 0.46 & 0.35 & 0.5 \\
\hline \multicolumn{8}{|c|}{ Tana, silty virgin } \\
\hline $0-7$ & 21 & 70 & 9 & - & - & - & 6.3 \\
\hline $7-25$ & 26 & 67 & 7 & 1.14 & 0.58 & 0.26 & 0.8 \\
\hline \multicolumn{8}{|c|}{ Tana, silty cultivated } \\
\hline $0-5$ & 51 & 44 & 5 & 1.53 & 0.43 & 0.06 & 2.5 \\
\hline $5-23$ & 48 & 46 & 6 & 1.44 & 0.46 & 0.07 & 2.0 \\
\hline $23-36$ & 65 & 31 & 3 & 1.49 & 0.47 & 0.18 & 0.4 \\
\hline
\end{tabular}

weed species with meadow grass (Poa annua) as the dominant species (Sveistrup 1992). The grass was cut for silage once a season, and the meadow was used for grazing for two weeks in late August during the previous four years (7.3 cows $\left.\mathrm{ha}^{-1}\right)$. During the same periods as for the meadow, cows (approx. 3.6 cows ha ${ }^{-1}$ ) grazed the forest area.

The soils of the Pasvik location had no particular agronomic problems. The studied site was situated on the edge of a peat bog, which was drained by open ditches of approximately $1 \mathrm{~m}$ depth and cultivated seven years prior to the investigations. A shallow peat layer $(20-30 \mathrm{~cm})$ covered a layer of outwashed sand more than 1 $\mathrm{m}$ thick, over sedimentary clay. The cultivated and the virgin sites were situated on either side of an open drainage ditch. The vegetation at the virgin site, was mostly peat moss (Sphagnum spp.), with heather (Ericaceae spp.) and scattered pine trees (Pinus sylvestris). The cultivated site had a five-year-old ley, mainly consisting of smooth meadow grass (Poa pratensis) and timothy (Phleum pratense). The ley was harvested once a year for silage and not grazed later in the season. The weight of the tractors, which had been used in recent years, was approximately 3 $\mathrm{Mg}$ at both Tana and Pasvik (Sveistrup 1992). According to Myhr and Njøs (1983) slurry application and one harvest will represent a wheel track cover of $133 \%$.

Undisturbed soil monoliths were collected at each site in rigid plastic cylinders. The cylinders were designed to be used as lysimeters. The inner diameter was $23.5 \mathrm{~cm}$ and the soil monoliths had a height of $25 \pm 1 \mathrm{~cm}$. Twelve monoliths were collected at each site, within a radius of $1.5 \mathrm{~m}$, and transported to Holt Research Station. The distance between the virgin and cultivated soils was approximately $15 \mathrm{~m}$.

In order to avoid influence of different vegetation and differences in humus content between the virgin and cultivated soils, the vegetation on the sites and the humus/peat layer were carefully removed before digging. Samples were taken from the same depth in the mineral soils both at the virgin and the cultivated soils. The soil was removed around the plastic cylinders, as they 


\section{Haraldsen, T.K. Effects of cattle slurry and cultivation on air exchange}

were pressed down to enclose the soil monoliths. A layer of grease was applied to the inside of the cylinder walls before sampling to ensure firm contact between wall and soil. The soil in the cylinders was collected from the plough layer and the top of the horizon below at the cultivated sites, and from the upper part of the mineral soil at the virgin sites. The depth of ploughing was approximately $20 \mathrm{~cm}$ both at Pasvik and Tana. Because of vibration during transportation the virgin soil from Pasvik had compacted and this caused somewhat higher bulk density than in its natural state.

The soil monoliths were used in a laboratory infiltration experiment at Holt Research Station (Haraldsen and Sveistrup 1994) before the start of the air exchange studies. In the experiment (Haraldsen and Sveistrup 1994) the following treatments were applied; (i) no cattle slurry (NCS), (ii) fresh cattle slurry (FCS), equivalent to $50 \mathrm{Mg} \mathrm{ha}^{-1}$, (iii) cattle slurry aerated for 4 weeks at $37^{\circ} \mathrm{C}$ (ACS), equivalent to $50 \mathrm{Mg} \mathrm{ha}^{-1}$.

The fresh slurry had $7.3 \%$ dry matter and the aerated slurry had $7.0 \%$ dry matter. The cattle slurry was from the same source as the slurry used at Holt in the experiment of Myhr et al. (1990). The slurry was applied evenly on the soil surface. The temperature in the laboratory was kept constant at $10 \pm 2^{\circ} \mathrm{C}$. At the start of the experiment there were four replicates. After the infiltration measurements, one week after slurry application, soil cores (height $5 \mathrm{~cm}$, volume $203.5 \mathrm{~cm}^{3}$ ) for soil physical analyses were collected from replicate 1 . The sampling depth was $0-5 \mathrm{~cm}$. Because of the slurry layer at the top, the volume of the soil in each cylinder was not exactly $203.5 \mathrm{~cm}^{3}$. The height of the soil in the cylinders was measured with accuracy of 0.5 $\mathrm{mm}$, and all soil physical data were corrected for the real volume of the soil. Three soil cores for each treatment were taken. A thin layer of grease was applied to the inside of the cylinders. The soil cores were packed in transport cases and transported by car to the Swedish University of Agricultural Sciences, Uppsala, where the samples arrived in good conditions.

After the infiltration measurements, one month after slurry application, soil cores were taken from replicate 2 in the same way. These soil cores were also packed in transport cases, and sent to Uppsala in Sweden by mail. Unfortunately, the virgin soil from Pasvik had subsided during the transport. With exception of two cores this soil could not be used in further analyses. The soil in two cores with virgin soil from Tana had also subsided and was not analysed.

\section{Laboratory methods}

The following parameters were determined for all samples; dry bulk density $\left(\gamma_{t}\right)$, density of solids $\left(\gamma_{s}\right)$ (Andersson 1955), diffusivity at different water potentials (D), air permeability coefficient at different water potentials $\left(\mathrm{K}_{\mathrm{a}}\right)$ and loss on ignition, $\left(\mathrm{g} 100 \mathrm{~g}^{-1}\right)$. The temperature in the laboratory was $20 \pm 2^{\circ} \mathrm{C}$.

Moisture retention curves were determined by using porous ceramic plates operated by suction (Andersson 1971). The samples were first saturated from below, then the water release characteristic and air-filled porosities were determined at water potentials equivalent to -0.5 , $-1.5,-3.0,-5.0,-10$ and $-60 \mathrm{kPa}$. Water potentials between 0 and including $-5.0 \mathrm{kPa}$ were obtained by a suspended, hanging column of water, those at -10 and $-60 \mathrm{kPa}$ by a vacuum pump. After equilibrium was attained at each tension, the samples were weighed and transferred to equipment for determining $\mathrm{D}$ and $\mathrm{K}_{\mathrm{a}}$. The airfilled porosity $\left(E_{\mathrm{g}}, \mathrm{m}^{3} \mathrm{~m}^{-3}\right)$ at a given water potential is here defined as the difference between volumetric water content at saturation (E) and volumetric water content $\left(\mathrm{E}_{\mathrm{w}}\right)$ at that water potential. When all measurements had been carried out at all water potentials, the samples were dried at $105^{\circ} \mathrm{C}$ for 72 hours.

Gas diffusivities of the soils were determined in an apparatus described by Edling (1986) which uses a transient state principle. The soil samples were left in the soil cores and a steel chamber of equal dimension was fitted above each, with an airtight seal. The chamber was flushed with $\mathrm{N}_{2}$ gas for 120 seconds via a valve, which was the 
Vol. 8 (1999): 29-44.

sealed. After a diffusion period of 3-10 minutes, depending on the water potential, gas samples $(50 \mu \mathrm{l})$ were taken from the chamber using a Hamilton gas-tight syringe at a sampling septum on the upper surface. $\mathrm{N}_{2}$ concentrations were analysed by a Gas Chromatograph (Hewlett Packard 5880A with Molecular Sieve 13 X column). 12 soil cores could be analysed in a series. Gaseous diffusion is usually expressed as relative diffusivity $\left(\mathrm{D} / \mathrm{D}_{0}\right)$, the ratio between diffusion of a gas through bulk soil (D) and in air $\left(D_{0}\right)$. The gas used in this experiment, $\mathrm{N}_{2}$, has a $\mathrm{D}_{0}$ of $20.1 \mathrm{~mm}^{2} / \mathrm{s}$ at $20^{\circ} \mathrm{C}$ (Armstrong 1979). Diffusion coefficient for the soil sample was calculated from the rate of decrease in the $\mathrm{N}_{2}$ concentration in the chamber. The time interval for diffusion ranged from 48 hours for the silty soil at $-1.5 \mathrm{kPa}$ water potential to 10 minutes for the sandy soil at $-60 \mathrm{kPa}$ water potential.

After the diffusion measurements, the samples were transferred to an apparatus for determination of air permeability, described by Andersson 1969), in which the volume of air drawn through the soil sample as a result of pressure differential of between 1 and $400 \mathrm{~Pa}$ is measured for a 120 seconds period. Air permeability is expressed as $\mathrm{K}, \mu \mathrm{m}^{2}$. Because zero air permeability was measured in some samples, logtransformation of air permeability was made by the equation (1).

$\log \mathrm{K}_{\mathrm{a}}=\log 10\left(\mathrm{~K}_{\mathrm{a}}+0.01\right)$

In this experiment 3 to 6 parallel samples per treatment have been used. Green and Fordham (1975) recommend eight to ten air permeability measurements per site, although good correlation with soil moisture content and air content has been detected with as few as four cores per site.

\section{Statistical methods}

The statistical analyses were conducted in the SAS-programme package. Stepwise multiple regressions were calculated by use of the procedure REG and a significance level of 0.05 was used. To test if the slurry treatments gave different regression equations, the homogeneity-ofslopes model in the procedure GLM was used (SAS Institute Inc. 1987). Outliers, which were due to clear errors in laboratory measurements, were removed before the statistical analyses.

\section{Results and discussion}

\section{Air-filled porosity}

According to Cassel and Nielsen (1986) an airfilled porosity of $0.1 \mathrm{~m}^{3} \mathrm{~m}^{-3}$ at field capacity is often quoted as a limit below which aeration is inadequate. A water potential of $-10 \mathrm{kPa}$ is often used as an approximation of "field capacity" (Cassel and Nielsen 1986). The sandy soil from Pasvik in this investigation is permeable to water and has a field capacity near to $-10 \mathrm{kPa}$. The silty soil from Tana has a field capacity at a water potential of $-5 \mathrm{kPa}$. This is due to the layers of the soil with approximately $50 \mathrm{~cm}$ of silt loam over the sandy layer.

The measurements of air-filled porosity at different water potentials (Table 2) showed a high variability both between samples from the same replicates and between the two replicates. There were no systematic trends in air-filled porosities between the two replicates (data not shown).

The air-filled porosity was lower both in the cultivated sandy Pasvik soil and the silty Tana soil than in the virgin soils. The values of airfilled porosity of the cultivated Pasvik soil were above the critical limit for aeration at $-10 \mathrm{kPa}$ water potential. The virgin and cultivated Tana soils had too low air-filled porosity for adequate plant growth at $-5 \mathrm{kPa}$ water potential. In the virgin state the Tana soil had higher air-filled porosity than the critical limit at $-10 \mathrm{kPa}$ water potential.

The slurry treatments did not influence airfilled porosity at any tension in the investigated soils. However, at $-60 \mathrm{kPa}$ water potential the 
Haraldsen, T.K. Effects of cattle slurry and cultivation on air exchange

Table 2. Air-filled porosity $\left(\mathrm{m}^{3} \mathrm{~m}^{-3}\right)$ at different water potentials for virgin and cultivated soils from Pasvik and Tana. Sampling depth $0-5 \mathrm{~cm}$ (SE=standard error).

\begin{tabular}{|c|c|c|c|c|c|c|c|}
\hline \multirow[b]{3}{*}{ Location } & \multirow[b]{3}{*}{ Cultivation } & \multirow[b]{3}{*}{ Slurry } & \multicolumn{5}{|c|}{ Air filled porosity $\left(\mathrm{m}^{3} \mathrm{~m}^{-3}\right)$} \\
\hline & & & \multicolumn{5}{|c|}{ Applied potential, $\mathrm{kPa}$} \\
\hline & & & -1.5 & -3.0 & -5.0 & -10 & -60 \\
\hline \multirow[t]{6}{*}{ Pasvik } & \multirow[t]{6}{*}{ Virgin } & No & 0.035 & 0.074 & 0.172 & 0.285 & 0.355 \\
\hline & & $\mathrm{SE}(\mathrm{n}=3)$ & 0.005 & 0.012 & 0.008 & 0.003 & 0.003 \\
\hline & & Fresh & 0.046 & 0.097 & 0.212 & 0.300 & 0.335 \\
\hline & & $\operatorname{SE}(n=3)$ & 0.008 & 0.004 & 0.005 & 0.005 & 0.009 \\
\hline & & Aerated & 0.052 & 0.080 & 0.185 & 0.266 & 0.353 \\
\hline & & $\mathrm{SE}(\mathrm{n}=3)$ & 0.010 & 0.008 & 0.008 & 0.016 & 0.011 \\
\hline \multirow[t]{6}{*}{ Pasvik } & \multirow[t]{6}{*}{ Cultivated } & No & 0.038 & 0.040 & 0.066 & 0.165 & 0.265 \\
\hline & & $\operatorname{SE}(n=7)$ & 0.006 & 0.004 & 0.005 & 0.010 & 0.005 \\
\hline & & Fresh & 0.053 & 0.056 & 0.086 & 0.142 & 0.260 \\
\hline & & SE $(n=6)$ & 0.006 & 0.004 & 0.013 & 0.019 & 0.026 \\
\hline & & Aerated & 0.023 & 0.037 & 0.077 & 0.126 & 0.226 \\
\hline & & $\operatorname{SE}(n=4)$ & 0.006 & 0.009 & 0.006 & 0.009 & 0.010 \\
\hline \multirow[t]{6}{*}{ Tana } & \multirow[t]{6}{*}{ Virgin } & No & 0.047 & 0.045 & 0.053 & 0.105 & 0.302 \\
\hline & & $\mathrm{SE}(\mathrm{n}=5)$ & 0.009 & 0.007 & 0.010 & 0.023 & $\begin{array}{l}0.013 \\
(\mathrm{n}=3)\end{array}$ \\
\hline & & Fresh & 0.054 & 0.053 & 0.071 & 0.119 & 0.168 \\
\hline & & $\operatorname{SE}(n=6)$ & 0.009 & 0.007 & 0.011 & 0.014 & $\begin{array}{l}0.015 \\
(\mathrm{n}=5)\end{array}$ \\
\hline & & Aerated & 0.052 & 0.060 & 0.074 & 0.109 & 0.242 \\
\hline & & $\operatorname{SE}(n=6)$ & 0.009 & 0.013 & 0.018 & 0.018 & 0.026 \\
\hline \multirow[t]{6}{*}{ Tana } & \multirow[t]{6}{*}{ Cultivated } & No & 0.026 & 0.044 & 0.044 & 0.059 & 0.101 \\
\hline & & SE $(n=6)$ & 0.003 & 0.005 & 0.005 & 0.003 & 0.008 \\
\hline & & Fresh & 0.027 & 0.041 & 0.043 & 0.059 & 0.119 \\
\hline & & SE $(n=6)$ & 0.005 & 0.005 & 0.006 & 0.004 & 0.009 \\
\hline & & Aerated & 0.033 & 0.046 & 0.049 & 0.060 & 0.113 \\
\hline & & $\operatorname{SE}(n=6)$ & 0.006 & 0.007 & 0.007 & 0.006 & $\begin{array}{l}0.018 \\
(\mathrm{n}=5)\end{array}$ \\
\hline
\end{tabular}

virgin Tana soil with fresh slurry had significantly lower air-filled porosity than without slurry.

\section{Diffusion measurements}

Gas movement by diffusion in response to partial pressure gradients, rather than mass flow in response to total pressure gradients, is the main mechanism by which gas exchange occurs in soils (Buckingham 1904, Romell 1922).

At $-1.5 \mathrm{kPa}$ water potential there was a high variability between replicate samples of all treat- ments (Table 3). Because of the high variability at this water potential, no effects of cultivation or slurry treatment on diffusion were detected. The variability probably reflects differences in pore continuity, caused by water films making "bottlenecks" in coarse continuous pores or making the pores discontinuous. At lower water potentials the relative variability was lower. This was also found by Lindström and McAfee (1987).

Both the sandy soil from Pasvik and the silty soil from Tana generally had higher relative diffusivities in virgin state than when cultivated. 
Vol. 8 (1999): 29-44.

Table 3. Relative diffusivity $\left(\mathrm{D} / \mathrm{D}_{0}\right)$ at different water potentials for virgin and cultivated soils from Pasvik and Tana. Sampling depth $0-5 \mathrm{~cm}$. SE=standard error.

\begin{tabular}{|c|c|c|c|c|c|c|c|}
\hline \multirow[b]{3}{*}{ Location } & \multirow[b]{3}{*}{ Cultivation } & \multirow[b]{3}{*}{ Treatment } & \multicolumn{5}{|c|}{ Relative diffusivity $\left(\mathrm{D} / \mathrm{D}_{0}\right)$} \\
\hline & & & \multicolumn{5}{|c|}{ Applied potential, $\mathrm{kPa}$} \\
\hline & & & -1.5 & -3.0 & -5.0 & -10 & -60 \\
\hline \multirow[t]{6}{*}{ Pasvik } & \multirow[t]{6}{*}{ Virgin } & No & 0.00038 & 0.0033 & 0.0238 & 0.0945 & 0.167 \\
\hline & & $\operatorname{SE}(n=3)$ & 0.00017 & 0.0009 & 0.0028 & 0.0046 & 0.010 \\
\hline & & Fresh & 0.00015 & 0.0051 & 0.0137 & 0.0448 & 0.063 \\
\hline & & SE $(n=3)$ & 0.00008 & 0.0016 & 0.0021 & 0.0019 & 0.005 \\
\hline & & Aerated & 0.00028 & 0.0062 & 0.0173 & 0.0425 & 0.104 \\
\hline & & $\operatorname{SE}(n=3)$ & 0.00014 & 0.0021 & 0.0027 & 0.0051 & 0.004 \\
\hline \multirow[t]{6}{*}{ Pasvik } & \multirow[t]{6}{*}{ Cultivated } & No & 0.00116 & - & 0.0058 & 0.0194 & 0.068 \\
\hline & & $\mathrm{SE}(\mathrm{n}=7)$ & 0.00064 & - & 0.0010 & 0.0011 & 0.002 \\
\hline & & Fresh & 0.00041 & - & 0.0040 & 0.0110 & 0.042 \\
\hline & & $\operatorname{SE}(n=6)$ & 0.00011 & - & 0.0016 & 0.0028 & 0.009 \\
\hline & & Aerated & 0.00049 & - & 0.0048 & 0.0116 & 0.036 \\
\hline & & $\operatorname{SE}(n=4)$ & 0.00032 & - & 0.0012 & 0.0021 & $\begin{array}{l}0.003 \\
(\mathrm{n}=3)\end{array}$ \\
\hline \multirow[t]{6}{*}{ Tana } & \multirow[t]{6}{*}{ Virgin } & NCS & 0.00045 & - & 0.0023 & 0.0092 & 0.072 \\
\hline & & $\mathrm{SE}(\mathrm{n}=5)$ & 0.00022 & - & $\begin{array}{c}0.0010 \\
(n=4)\end{array}$ & $\begin{array}{c}0.0030 \\
(n=4)\end{array}$ & $\begin{array}{l}0.008 \\
(n=3)\end{array}$ \\
\hline & & Fresh & 0.00045 & - & 0.0045 & 0.0100 & 0.010 \\
\hline & & $\mathrm{SE}(\mathrm{n}=6)$ & 0.00024 & - & $\begin{array}{c}0.0016 \\
(n=4)\end{array}$ & $\begin{array}{c}0.0022 \\
(n=5)\end{array}$ & $\begin{array}{l}0.003 \\
(n=3)\end{array}$ \\
\hline & & Aerated & 0.00237 & - & 0.0069 & 0.0106 & 0.026 \\
\hline & & $\mathrm{SE}(\mathrm{n}=6)$ & 0.00073 & - & 0.0006 & $\begin{array}{c}0.0016 \\
(n=5)\end{array}$ & $\begin{array}{l}0.005 \\
(n=5)\end{array}$ \\
\hline \multirow[t]{6}{*}{ Tana } & \multirow[t]{6}{*}{ Cultivated } & No & 0.00039 & - & 0.0016 & 0.0055 & 0.013 \\
\hline & & $\operatorname{SE}(n=6)$ & 0.00027 & - & 0.0006 & 0.0001 & 0.002 \\
\hline & & Fresh & 0.00031 & - & 0.0005 & 0.0043 & 0.012 \\
\hline & & $\mathrm{SE}(\mathrm{n}=6)$ & 0.00026 & - & 0.0001 & 0.0013 & 0.002 \\
\hline & & Aerated & 0.00035 & - & 0.0012 & 0.0050 & 0.014 \\
\hline & & $\mathrm{SE}(\mathrm{n}=6)$ & 0.00016 & - & 0.0005 & $\begin{array}{c}0.0017 \\
(n=5)\end{array}$ & $\begin{array}{l}0.004 \\
(n=4)\end{array}$ \\
\hline
\end{tabular}

Diffusion is highly related to air-filled porosity $\left(\mathrm{E}_{\mathrm{g}}\right)$. As already mentioned, air-filled porosity showed a high variability both between samples from the same replicates and between replicates. The relationship between relative diffusivity $(\mathrm{D} /$ $\mathrm{D}_{0}$ ) and porosity/air-filled porosity is described in the literature through various types of equations (Buckingham 1904, Penman 1940, Marshall 1959, Millington 1959, Currie 1960, 1961, Bakker and Hidding 1970, Stepniewski 1981, Ball et al. 1988). Many of these authors have described the relationship between $\mathrm{D} / \mathrm{D}_{0}$ and $\mathrm{E}_{\mathrm{g}}$ by equation (2).

$\mathrm{D} / \mathrm{D}_{0}=\mathbf{a} \mathrm{E}_{\mathrm{g}}^{\mathbf{b}}$

According to Stepniewski (1981) the value of coefficient $\mathbf{a}$ is associated with the total porosity of the soil, whereas $\mathbf{b}$ is associated with air content and continuity of pores filled with air. In the literature values of $\mathbf{a}$ in the range of $0.15-40\left(E_{g}, m^{3} \mathrm{~m}^{-3}\right)$ have been presented, while the reported values of $\mathbf{b}$ are in the range of 0.8 
Haraldsen, T.K. Effects of cattle slurry and cultivation on air exchange

Table 4. Influence of slurry application on the relationship between relative diffusivity $\left(\mathrm{D} / \mathrm{D}_{0}\right)$ and airfilled porosity $(\mathrm{Eg})$.

\begin{tabular}{|c|c|c|c|c|c|}
\hline Location & Cultivation & Slurry & Regression equation & $\mathrm{n}$ & $\mathrm{R}^{2}$ \\
\hline Pasvik & Virgin & $\begin{array}{l}\text { No } \\
\text { Aerated } \\
\text { Fresh }\end{array}$ & $\begin{array}{l}\mathrm{D} / \mathrm{D}_{0}=-0.0074+1.34 \mathrm{Eg}^{2} \\
\mathrm{D} / \mathrm{D}_{0}=-0.0042+0.80 \mathrm{E}_{\mathrm{g}}^{2} \\
\mathrm{D} / \mathrm{D}_{0}=-0.0035+0.55 \mathrm{E}_{\mathrm{g}}^{2}\end{array}$ & $\begin{array}{l}15 \\
15 \\
14\end{array}$ & $\begin{array}{l}0.98 \\
0.94 \\
0.95\end{array}$ \\
\hline Pasvik & Cultivated & $\begin{array}{l}\text { No } \\
\text { Aerated } \\
\text { Fresh }\end{array}$ & $\begin{array}{l}\mathrm{D} / \mathrm{D}_{0}=-0.00042+0.92 \mathrm{E}_{\mathrm{g}}^{2} \\
\mathrm{D} / \mathrm{D}_{0}=0.0009+0.61 \mathrm{E}_{\mathrm{g}}^{2} \\
\mathrm{D} / \mathrm{D}_{0}=-0.0016+0.62 \mathrm{E}_{\mathrm{g}}{ }^{2}\end{array}$ & $\begin{array}{l}28 \\
18 \\
24\end{array}$ & $\begin{array}{l}0.94 \\
0.88 \\
0.95\end{array}$ \\
\hline Tana & Virgin & $\begin{array}{l}\text { No } \\
\text { Aerated } \\
\text { Fresh }\end{array}$ & $\begin{array}{l}\mathrm{D} / \mathrm{D}_{0}=-0.0013+0.79 \mathrm{E}_{\mathrm{g}}^{2} \\
\mathrm{D} / \mathrm{D}_{0}=0.003+0.37 \mathrm{E}_{\mathrm{g}}^{2} \\
\mathrm{D} / \mathrm{D}_{0}=0.0015+0.35 \mathrm{E}_{\mathrm{g}}^{2}\end{array}$ & $\begin{array}{l}16 \\
22 \\
17\end{array}$ & $\begin{array}{l}0.98 \\
0.93 \\
0.57\end{array}$ \\
\hline Tana & Cultivated & $\begin{array}{l}\text { No } \\
\text { Aerated } \\
\text { Fresh }\end{array}$ & $\begin{array}{l}\mathrm{D} / \mathrm{D}_{0}=-0.0039+0.16 \mathrm{E}_{\mathrm{g}} \\
\mathrm{D} / \mathrm{D}_{0}=-0.0029+0.11 \mathrm{E}_{\mathrm{g}} \\
\mathrm{D} / \mathrm{D}_{0}=-0.0027+0.11 \mathrm{E}_{\mathrm{g}}\end{array}$ & $\begin{array}{l}24 \\
21 \\
24\end{array}$ & $\begin{array}{l}0.84 \\
0.58 \\
0.59\end{array}$ \\
\hline
\end{tabular}

4 (Glinski and Stepniewski 1985). Lindström and McAfee (1987) gave values of $\mathbf{a}$ in the range of $0.1-0.7$, using the same method as in the present investigation on relatively impermeable soils. Their b values were 1.4 to 3.3 .

Different regression models were tested, both exponential (like equation (2)), quadratic, polynomial and linear. A regression equation for each slurry treatment was made in order to see if the relationship between relative diffusivity $\left(\mathrm{D} / \mathrm{D}_{0}\right)$ and air-filled porosity $\left(\mathrm{E}_{\mathrm{g}}\right)$ had changed. The relationship was fitted with quadratic equations on the Pasvik soils, and on the virgin Tana soil. Best fit for the cultivated Tana soil was obtained by linear equations (Table 4).

For the virgin sandy soil from Pasvik there was a significantly steeper slope on the regression line for the treatment without slurry than for the slurry treatments $(\mathrm{P}<0.001)$, and there was a significant difference between the slurry treatments $(\mathrm{P}<0.01)$ (Fig. 1). Infiltration measurements (Haraldsen and Sveistrup 1994) for replicate 1 showed higher infiltration for aerated slurry than for fresh slurry. However, the infiltration rate for replicate 1 was considerably higher after application of aerated slurry than for the other three replicates. After application of fresh slurry replicate 1 showed a slightly higher infiltration rate than the other three replicates, and the difference in infiltration rate between the FCS and ACS treatments was not significant (Haraldsen and Sveistrup 1994). Therefore, the real difference in diffusivity between the ACS and FCS treatments may be less than measured for replicate 1 . Unfortunately the samples from replicate 2 for the virgin sandy soil from Pasvik was disturbed by transport. In the micromophological investigations (Sveistrup et al. 1995) the virgin Pasvik soil was described as fairly heterogeneous, and results from different replicates would be important when interpreting the results of different soil physical measurements.

For the cultivated sandy soil from Pasvik there was a significantly steeper slope on the regression line for the treatment without slurry than for the slurry treatments $(\mathrm{P}<0.001)$ and no significant difference between the slurry treatments (P>0.05) (Table 4, Fig. 2).

Micromorphological studies of soil samples from the Pasvik soil showed that the slurry did not affect the microstructure (Sveistrup et al. 1995). The slurry was present as a more or less continuous layer of variable thickness on the soil surface. The slurry layer had two phases: (i) a layer of raw, undecomposed but fragmented straw on top of (ii) a layer of homogeneous, colloidal, pale yellowish brown material. Except for a few thin coatings in the uppermost $50 \mu \mathrm{m}$, there 
Vol. 8 (1999): 29-44.

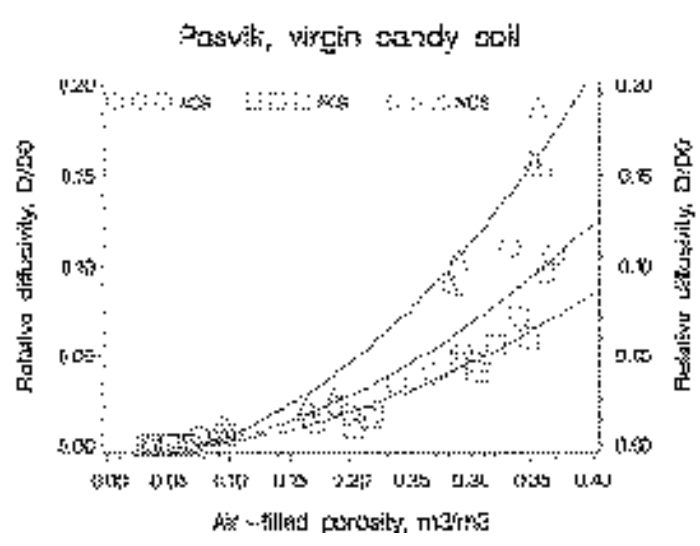

Fig. 1. Relative diffusivity $\left(\mathrm{D} / \mathrm{D}_{0}\right)$ at different air-filled porosities $\left(E_{g}\right)$ for the virgin sandy soil from Pasvik (NCS=no slurry, FCS=fresh slurry, ACS=aerated slurry).

was no evidence of penetration of organic matter into the mineral soil. No clear differences between aerated and fresh slurry were found. Stevens and Cornforth (1974) found that large amounts of slurry could completely seal the soil surface. The sealing effect was obtained with fresh slurry, sieved slurry, and with fine solids, but not with coarse solids, supernatant or water. The results from Stevens and Cornforth (1974) indicated that the colloidal organic matter in the slurry, which overlied the mineral soil, represented a barrier for gas diffusion. The diffusivity of this thin layer was less than in the sandy soil. Burford (1976) concluded that the high water content in the slurry and particulate organic matter restricted aeration in the soil.

In the present experiment a smaller air-filled porosity and relative diffusivity in the cultivated soils, as compared to the virgin soils, were found. Sveistrup et al. (1995) found that the cultivated Pasvik soil was richer in fine mineral particles than the virgin one. Differences in soil structure were also observed, single grained in the virgin soil and microaggregates, pellicular or bridged-grain microstructures in the cultivated soil. Table 1 also shows higher silt and clay contents in the top layer of the cultivated Pasvik soil compared to the virgin soil. Because of the textural differences between the cultivated and

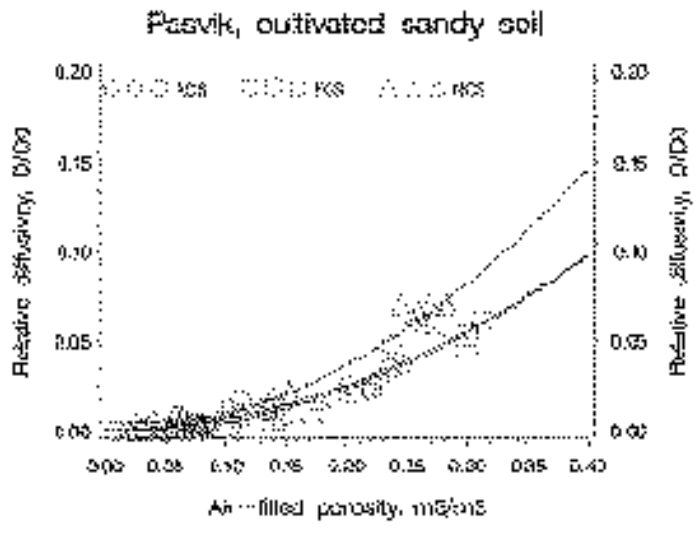

Fig. 2. Relative diffusivity $\left(\mathrm{D} / \mathrm{D}_{0}\right)$ at different air-filled porosities $\left(\mathrm{E}_{\mathrm{g}}\right)$ for cultivated sandy soil from Pasvik (NCS=no slurry, $\mathrm{FCS}=$ fresh slurry, $\mathrm{ACS}=$ aerated slurry).

virgin soils, this probably partly explains the lower air-filled porosity and smaller diffusivity in the cultivated Pasvik soil, which is not a result of compaction by agricultural machines but could be a result of mixing soil layers during cultivation.

For the virgin silty soil from Tana there were significant differences between the equations of the NCS treatment and the slurry treatments $(\mathrm{P}<0.001)$. The equations for the FCS and ACS treatments were not significantly different (P>0.05) (Fig. 3, Table 4). The poorer $\mathrm{R}^{2}$ for the FCS treatment was partly due to a high variation between replicate samples, and partly due to lower air-filled porosity at $-60 \mathrm{kPa}$ water potential (Table 2). Sveistrup et al. (1995) reported some variations in structure between the treatments; micromorphological studies showed higher density in the ACS and FCS treatments than at the NCS treatment. The samples investigated by Sveistrup et al. (1995) were from replicates 1 and 3 in the infiltration experiment (Haraldsen and Sveistrup 1994). As mentioned earlier, samples from replicates 1 and 2 were used in the present experiment.

For the cultivated silty soil from Tana there were no significant differences between the regression equations for the different treatments $(P>0.05)$ (Table 4, Fig. 4). Since the slurry treat- 
Haraldsen, T.K. Effects of cattle slurry and cultivation on air exchange

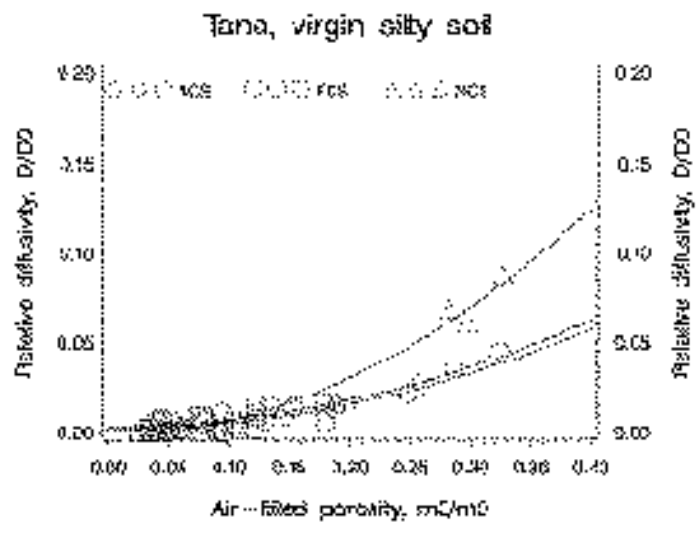

Fig. 3. Relative diffusivity $\left(\mathrm{D} / \mathrm{D}_{0}\right)$ at different air-filled porosities $\left(\mathrm{E}_{\mathrm{g}}\right)$ for virgin silty soil from Tana (NCS=no slurry, $\mathrm{FCS}=$ fresh slurry, ACS=aerated slurry).

ments did not influence the relationship between $\mathrm{D} / \mathrm{D}_{0}$ and $\mathrm{E}_{\mathrm{g}}$, it seems safe to conclude that the gas diffusivity was not limited by the slurry layer at the top but rather by the soil itself.

The study of micromorphological features in the virgin and cultivated Tana soils showed a clear difference in structure and porosity due to cultivation. The virgin Tana soil had a well-developed granular microstructure in the upper 1 $\mathrm{cm}$ and a partly compacted platy structure with lens-shaped aggregates in deeper layers. The cultivated soil was massive or had a weakly developed blocky microstructure (Sveistrup et al. 1995). A comparison of figures 3 and 4 clearly shows that the cultivated Tana soil had less airfilled porosity and lower relative diffusivity than the virgin silty soil from Tana.

The critical limit for relative diffusivity $\left(\mathrm{D} / \mathrm{D}_{0}\right)$ below which crop growth is affected is in the range of 0.005-0.02 (Grable and Siemer 1968). Boone et al. (1986) showed that the oxygen consumption in the soil greatly influenced the critical limits for the oxygen diffusion coefficient, and soil compaction was found to increase the oxygen consumption in the soil. At field capacity $(-5 \mathrm{kPa})$ both the uncultivated and cultivated Tana soils had lower relative diffusivity than the lower limit of Grable \& Siemer (1968). This result is not surprising due to the

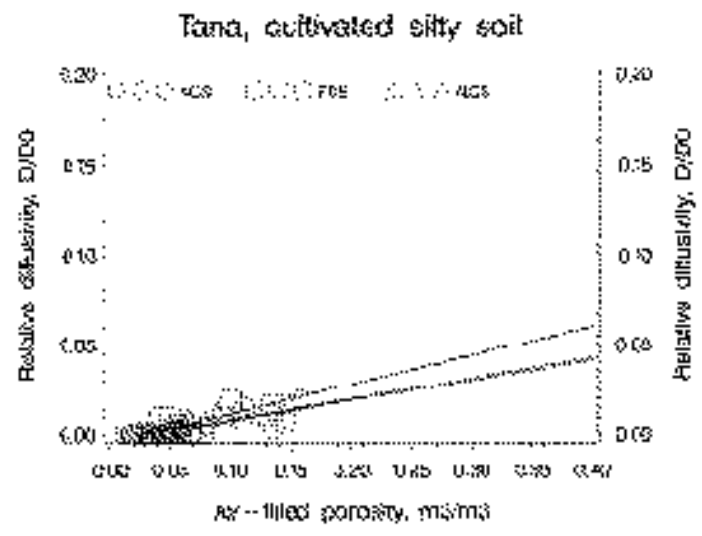

Fig. 4. Relative diffusivity $\left(\mathrm{D} / \mathrm{D}_{0}\right)$ at different air-filled porosities $\left(\mathrm{E}_{\mathrm{g}}\right)$ for cultivated silty soil from Tana $(\mathrm{NCS}=$ no slurry, FCS=fresh slurry, ACS=aerated slurry).

great problems with grass growth at this site (Lorentzen 1984), and the large amount of weed grasses (Poa annua) observed. Application of slurry to the Tana soil will increase the oxygen demand in the soil and would make the soil more anaerobic (Egginton and Smith 1986). Application of slurry to this type of soil will therefore have negative impacts on grass growth due to poor aeration. At field capacity $(-10 \mathrm{kPa})$ the uncultivated sandy Pasvik soil had a higher relative diffusivity than the limit of Grable and Siemer (1968). The cultivated Pasvik soil without slurry application had a relative diffusivity close to 0.02 , while slurry application reduced the $\mathrm{D} /$ $\mathrm{D}_{0}$ relationship to $0.011-0.012$. However, slurry is normally applied in practical farming on this soil without any problems for grass growth.

\section{Air permeability measurements}

The variability in air permeability between parallel samples was high, especially for the samples from the Tana soil. However, this high variability probably caused that slurry application did not significantly influence the effects on the relationship between air permeability $\left(\mathrm{K}_{\mathrm{a}}\right)$ and air-filled porosity $\left(\mathrm{E}_{\mathrm{g}}\right)$, in neither the Pasvik or Tana soils. 
Vol. 8 (1999): 29-44.

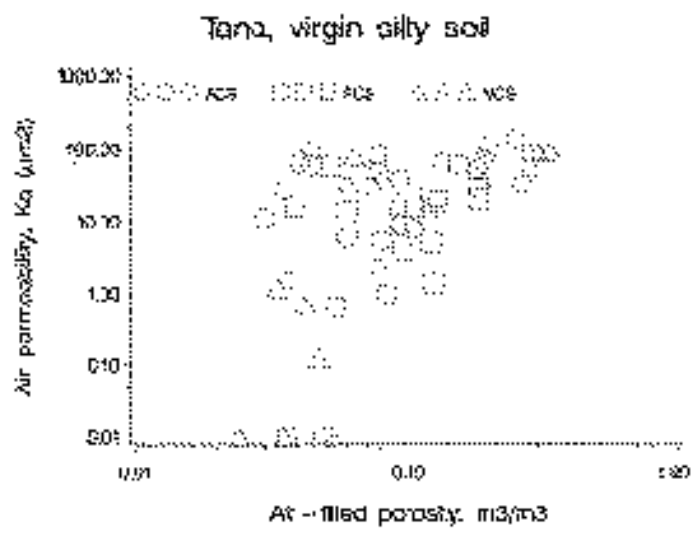

Fig. 5. Air permeability $\left(\mathrm{K}_{\mathrm{a}}, \mu \mathrm{m}^{2}\right)$ at different air-filled porosities $\left(\mathrm{E}_{\mathrm{g}}\right)$ for virgin silty soil from Tana (NCS=no slurry, $\mathrm{FCS}=$ fresh slurry, $\mathrm{ACS}=$ aerated slurry).

Air permeability and air-filled porosities were fitted to the equation (3):

$\log \mathrm{K}_{\mathrm{a}}=\log \mathrm{M}+\mathrm{N} \log \mathrm{E}_{\mathrm{g}}$

where $\mathrm{M}$ and $\mathrm{N}$ are empirical constants (Ball et al. 1988). Values of $M, N$ and $R^{2}$ are given in Table 5. The poor correlation between $\mathrm{K}_{\mathrm{a}}$ and $\mathrm{E}_{\mathrm{g}}$ for the Tana soils was influenced by variability in continuity and size distribution of air-filled pores (Fig. 5 and 6). The wide range of $\mathrm{E}_{\mathrm{g}}$-values which give an air permeability of zero (in Figs. 5 and 6 is 0 represented by 0.01 ) is a significant indication of this (Ball 1987, Ball et al. 1988). Edling (1986) found a similar variability of results as in the present investigation. Samples having identical air content could have air permeability values which differed by 1000 times. In some of Edlings samples a relatively

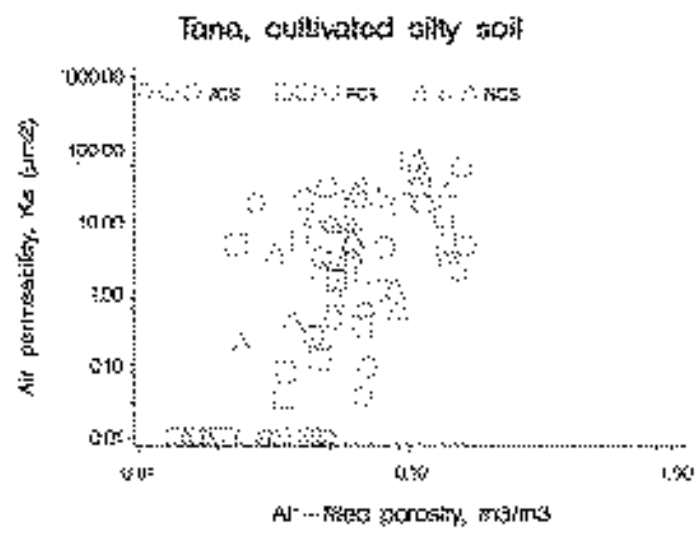

Fig. 6. Air permeability $\left(\mathrm{K}_{\mathrm{a}}, \mu \mathrm{m}^{2}\right)$ at different air-filled porosities $\left(E_{g}\right)$ for cultivated silty soil from Tana $(\mathrm{NCS}=$ no slurry, FCS=fresh slurry, ACS=aerated slurry).

high air permeability was found at air-filled porosities $<0.05$, while it was zero at this air content in other cases. In thin sections Sveistrup et al. (1995) observed that there was less pores in the upper $1 \mathrm{~cm}$ of the virgin Pasvik soil compared to at $3 \mathrm{~cm}$ depth. The lower percentage of pores close to the surface was probably a result of traffic by agricultural machinery (Sveistrup et al. 1995). The relatively poor relationship between $\mathrm{K}_{\mathrm{a}}$ and $\mathrm{E}_{\mathrm{g}}$ for the cultivated Pasvik soil may also indicate that this soil was influenced by continuity and size distribution of air-filled pores.

Blackwell et al. (1990) introduced the term pore organization, $\mathrm{O}$, which is dependent of the arrangement and shape of the macropore space, and defined by (4):

$\mathrm{O}=\mathrm{K}_{\mathrm{a}} / \mathrm{Eg}$

Table 5. Regression parameters from air permeabilities and air porosities for sandy soils from Pasvik and silty soils from Tana.

\begin{tabular}{llcccc}
\hline Soil & Cultivation & $\log \mathrm{M}$ & $\mathrm{N}$ & $\mathrm{R}^{2}$ & $\mathrm{n}$ \\
\hline Pasvik & Virgin & 2.54 & 2.02 & 0.76 & 43 \\
Pasvik & Cultivated & 2.19 & 1.47 & 0.56 & 70 \\
Tana & Virgin & 3.16 & 2.11 & 0.31 & 55 \\
Tana & Cultivated & 4.25 & 3.37 & 0.45 & 70 \\
\hline
\end{tabular}




\section{AGRICULTURAL AND FOOD SCIENCE IN FINLAND}

Haraldsen, T.K. Effects of cattle slurry and cultivation on air exchange

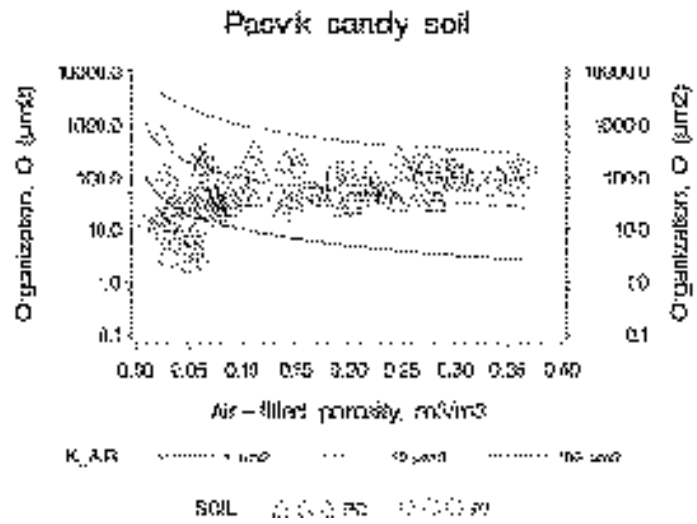

Fig. 7. Pore organization $\left(\mathrm{O}, \mu \mathrm{m}^{2}\right)$ at different air-filles porosities $\left(\mathrm{E}_{\mathrm{g}}\right)$ for cultivated sandy soil from Pasvik (PC) and virgin sandy soil from Pasvik (PV).

Pore organization was calculated for the Pasvik and Tana soils ( $\mathrm{K}_{\mathrm{a}}$ measurements of 0 was replaced by $0.01 \mu \mathrm{m}^{2}$ ) and plotted in graphs (Figs. 7 and 8) similar to the presentation of $\mathrm{O}$ by Blackwell et al. (1990). From Fig. 7 no clear evidence of different pore organization between the virgin and cultivated Pasvik soils can be observed. The variation in pore organization was largest for air-filled porosities $<0.1 \mathrm{~m}^{3} \mathrm{~m}^{-3}$. The pore organization of the Tana soils differed substantially from that of the Pasvik soils. At airfilled porosities $<0.1 \mathrm{~m}^{3} \mathrm{~m}^{-3}$ the virgin Tana soil was influenced by a massive matrix with blocked pores and some macropores involved in gas transmission, causing $\mathrm{O}$ to vary from 0.1 to more than $100 \mu \mathrm{m}^{2}$, while most of the $\mathrm{O}$-values ranged from 10 to more than $1000 \mu^{2}$ for the virgin Tana soil, which was better structured (Fig. 8).

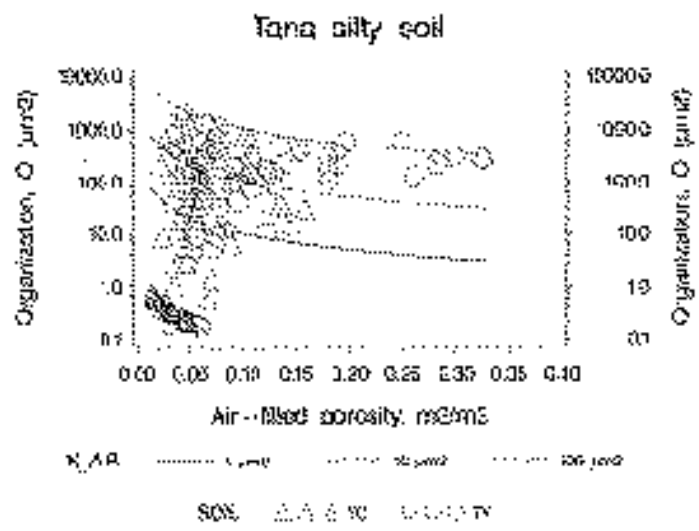

Fig. 8. Pore organization $\left(\mathrm{O}, \mu \mathrm{m}^{2}\right)$ at different air-filles porosities $\left(\mathrm{E}_{\mathrm{g}}\right)$ for cultivated silty soil from Tana (TC) and virgin silty soil from Tana (TV).

Gas transport by mass flow is less important in the soil than transport by diffusion (Romell 1922). Although soil air permeability per se is not a particularly important aeration parameter, it does reflect the soil's water permeability (McAfee et al. 1989). Theoretically the correlation between relative diffusivity $\left(\mathrm{D} / \mathrm{D}_{0}\right)$ and air permeability $\left(\mathrm{K}_{\mathrm{a}}\right)$ may vary greatly because continuity and pore size distribution of air-filled pores influence $\mathrm{D} / \mathrm{D}_{0}$ and $\mathrm{K}_{\mathrm{a}}$ in different ways. McAfee et al. (1989) found the relationship fitted by the equation $\mathrm{D} / \mathrm{D}_{0}=\mathrm{aK}_{\mathrm{a}}^{\mathrm{b}}$. In this study the relationship was found to be $\log -\log$ linear (Table 6).

The regression analysis showed that cultivation did not significantly affect the relationship between $\mathrm{D} / \mathrm{D}_{0}$ and $\mathrm{K}_{\mathrm{a}}$ for the Pasvik and Tana soils, but the relationship was significantly dif-

Table 6. Regression equations for the relationship relative diffusivity $\left(\mathrm{D} / \mathrm{D}_{0}\right)$ to air permeability $\left(\mathrm{K}_{\mathrm{a}}, \mu \mathrm{m}^{2}\right)$.

\begin{tabular}{lllll}
\hline Soil & Cultivation & Regression equation & $\mathrm{R}^{2}$ & $\mathrm{n}$ \\
\hline Pasvik & Virgin & $\log \mathrm{D} / \mathrm{D}_{0}=-2.95+1.09 \log \mathrm{K}_{\mathrm{a}}$ & 0.75 & 43 \\
Pasvik & Cultivated & $\log / \mathrm{D}_{0}=-2.98+1.03 \log \mathrm{K}_{\mathrm{a}}$ & 0.76 & 70 \\
Tana & Virgin & $\log / \mathrm{D}_{0}=-2.85+0.50 \log \mathrm{K}_{\mathrm{a}}$ & 0.65 & 53 \\
Tana & Cultivated & $\log / \mathrm{D}_{0}=-2.80+0.54 \log \mathrm{K}_{\mathrm{a}}$ & 0.77 & 69 \\
\hline
\end{tabular}


Vol. 8 (1999): 29-44.

ferent for the two soils. This difference between the two soils may be due to differences in pore continuity, tortuosity, constriction and size.

Because air permeability measurements are much less time consuming and do not require expensive equipment like a gas chromatograph, it would be of interest to predict relative diffusivity from air permeability. Because of the variability of air permeability results, the models are not particularly predictive. In this investigation all information about the sealing effect of slurry would have been lost if the relative diffusivity had been predicted from air permeability instead of being measured.

\section{Methodological problems}

One problem with this experiment is that there had to be differences in time between the measurements at the different water potentials. There was a time difference of about three months between the measurements at $-1.5 \mathrm{kPa}$ water potential and at $-60 \mathrm{kPa}$ water potential. During the time in the laboratory, growth of mycelium was observed in the slurry layer. The negative effect of slurry on gas diffusion, which was significant at $-10 \mathrm{kPa}$ and $-60 \mathrm{kPa}$, was obtained after at least two months in the laboratory at $20^{\circ} \mathrm{C}$. Therefore, the negative effects of slurry on gas movement in the soil seems to be a relatively persistent. A significant decrease in infiltration rate due to slurry application was found in the same soils after three month (Haraldsen and Sveistrup 1994).

The amounts of slurry used in this experiment gave a continuous cover of slurry on the soil surface. This experiment was carried out on soils without plant cover, and the slurry was probably more evenly applied than in practical farming. The methods used in this experiment did not enable a quantification of the real effects of slurry on gas movement in field. In field growth of grass, tunnelling of earthworms and dung fly larvae may perforate the continuous cover of slurry, and improve the aeration (Burford 1976, Haraldsen and Sveistrup 1996).

\section{Conclusions}

In a study from northern Norway lower air-filled porosities and relative diffusivities were found of cultivated sandy and silty soils than in virgin (uncultivated) soils. Application of slurry $(50 \mathrm{Mg}$ $\mathrm{ha}^{-1}$ ) reduced the relative diffusivity and changed the relationship between relative diffusivity and air-filled porosity for the virgin and the cultivated sandy soil and the virgin silty soil. There was no significant difference between aerated and fresh slurry on gas diffusion in the cultivated sandy soil and the virgin silty soil. However, there was a significant difference in the effects of aerated and fresh slurry on gas diffusion on the virgin sandy soil. The air permeability measurements showed a high variability, and no influence of slurry application on air permeability was found. The relationship between air-permeability and air-filled porosity was influenced by the variability in non-continuous air-filled porosity between replicate samples. This was especially pronounced in the silty soils. The virgin and cultivated silty soils used in this investigation had lower relative diffusivity at field capacity than the lower value of limit below which crop growth is affected. The dominance of weed grass (Poa annua) at the cultivated silty soil indicates a high risk for stress on sown grass species and winter damage.

Acknowledgements. Dr. Currie is thanked for valuable comments on the experimental methods and presentation of the results. Professors Njøs and Håkansson, and Dr. Riley are thanked for useful comments on the manuscript. Tore Sveistrup is thanked for sampling in field and valuable comments during the experimental phase and preparation of the manuscript. The Department of Soil Sciences at the Swedish University of Agricultural Sciences, Uppsala, is thanked for use of laboratory facilities during the author's stay in Sweden. 
Haraldsen, T.K. Effects of cattle slurry and cultivation on air exchange

\section{References}

Andersson, S. 1955. Markfysikaliska undersökningar i odlad jord. 8. En experimentell metod (in Swedish). Grunnförbättring 8 (specialnummer 2), 98 p.

- 1969. Markfysikaliska undersökningar i odlad jord. 19. Teoretiska modellstudier av kapillära systems kvärden som funktioner av porstorleksfördelning, bindingstryck och vattenhalt (in Swedish). Grundförbättring 22: 143-154.

- 1971. Markfysikaliska undersökningar i odlad jord. 22. Härledning av och några kommentarer kring en differentialekvation för vattents endimensionella strömning i omättad jord (in Swedish). Grundförbättring 24: 51-64.

Armstrong, W. 1979. Aeration in higher plants. Advances in Biological Research 7: 225-332.

Aune, B. 1993. Air Temperature Normals, Normal Period 1961-1990. The Norwegian Meteorological Institute, report 02/93 Climate, Oslo. $63 \mathrm{p}$.

Bakker, J.W. \& Hidding, A.P. 1970. The influence of soil structure and air content on gas diffusion in soils. Netherlands Journal of Agricultural Science 18: 3748.

Ball, B.C. 1981. Pore characteristics of soils from two cultivation experiments as shown by gas diffusivities and permeabilities and air-filled porosities. Journal of Soil Science 32: 483-498.

- 1987. Air permeability and gas diffusion measurements to quantify soil compaction. In: Monnier, G. \& Goss, M.J. (eds.). Soil Compaction and Regeneration. A.A. Balkema, Rotterdam. p. 15-24.

-, O'Sullivan, M.F. \& Hunter, R. 1988. Gas diffusion, fluid flow and derived pore continuity indices in relation to vehicle traffic and tillage. Journal of Soil Science 39: 327-339.

Blackwell, P.S., Ringrose-Voase, A.J., Jayawardne, N.S., Olsson, K.A., McKenzie, D.C. \& Mason, W.K. 1990. The use of air-filled porosity and intrisic permeability to air to characterize structure of macropore space and saturated hydraulic conductivity of clay soils. Journal of Soil Science 41: 215-228.

Boone, F.R., van der Werf, H.M.G., Kroesbergen, B., ten Hag, B.A. \& Boers, A. 1986. The effects of compaction of the arable layer in sandy soils on the growth of maize for silage. 1. Critical matric water potentials in relation to soil aeration and mechanical impedance. Netherland Journal of Agricultural Science 34: 155171.

Buckingham, E. 1904. Contribution to our knowledge of the aeration of soils. U.S. Department of Agriculture, Bureau of Soils, Bulletin 25. 52 p.

Burford, J.R. 1976. Effect of the application of cow slurry to grassland on the composition of soil atmosphere. Journal of the Science of Food and Agriculture 27: 115-126.

Cassel, D.K. \& Nielsen, D.R. 1986. Field capasity and available water capasity. In: Klute, A. (ed.). Methods of Soil Analyses, Part 1, Physical and Mineralogical Methods. 2nd edition. American Society of Agronomy. Agronomy Monograph 9. p. 901-926.
Currie, J.A. 1960. Gaseous diffusion in porous media. Part 2. Dry granular materials. British Journal of Applied Physics 11: 318-324.

- 1961. Gaseous diffusion in porous media. Part 3. Wet granular materials. British Journal of Applied Physics 12: $275-281$.

Douglas, J.T. \& Crawford, C.E. 1998. Soil compaction effects on utilization of nitrogen from livestock slurry applied to grassland. Grass and Forage Science 53: 31-40.

Edling, P. 1986. Soil Air. Volume and Gas Exchange Mechanisms. Department of Soil Sciences, Division of Agricultural Hydrotechnichs, Swedish University of Agricultural Sciences, 51. $132 \mathrm{p}$.

Egginton, G.M. \& Smith, K.A. 1986. Nitrous oxide emission from a grassland soil fertilized with slurry and calcium nitrate. Journal of Soil Science 37: 59-67.

FAO 1998. World Reference Base for Soil Resources. World Soil Resources Reports 84, FAO, Rome. 88 p.

Glinski, J. \& Stepniewski, W. 1985. Soil Aeration and Its Role for Plants. CRC Press, Boca Raton, Florida. 200 p.

Green, R.D. \& Fordham, S.J. 1975. A field method for determining air permeability in soil. In: Soil Physical Conditions and Crop Production. MAFF Technical Bulletin 29, HMSO, London. p. 273-288.

Grable, A.R. \& Siemer, E.G. 1968. Effects of bulk density, aggregate size, and soil water suction on oxygen diffusion, redox potentials, and elongation of corn roots. Soil Science Society of America Proceedings 32: 180-186.

Hansen, S. \& Bakken, L.R. 1993. $\mathrm{N}_{2} \mathrm{O}, \mathrm{CO}_{2}$ and $\mathrm{O}_{2}$ concentrations in soil air influenced by organic and inorganic fertilizers and soil compaction. Norwegian Journal of Agricultural Sciences 7: 1-10.

Haraldsen, T.K. \& Sveistrup, T.E. 1994. Effects of cattle slurry and cultivation on infiltration in sandy and silty soils from northern Norway. Soil \& Tillage Research 29: 307-321.

- \& Sveistrup, T.E. 1996. Influence of cattle slurry application and soil faunal activity on infiltration in soils from northern Norway. Norwegian Journal of Agricultural Sciences 10: 43-54.

Håland, Å. 1988. Blautgjødsel til ulike grasartar (in Norwegian, English abstract). Norwegian Agricultural Research 2: 233-244.

Labuda, S., Mackowiak, C. \& Stepniewski, W. 1976. Changes of air composition in soil fertilized with slurry. Polish Journal of Soil Science 10: 3-14.

Lindström, J. \& McAfee, M. 1987. Air and water movement in covers for mine waste. Swedish University of Agricultural Sciences, Department of Soil Sciences, Division of Agricultural Hydrotechnics, Report 153. $56 \mathrm{p}$.

Lorentzen, I. 1984. Jorda på Finnmark landbruksskole. En vurdering av problemer med overflatevann og overvintringsskader. M.Sc. thesis. Agricultural University of Norway. $84 \mathrm{p}$.

Marshall, T.J. 1959. The diffusion of gases through po- 
Vol. 8 (1999): 29-44.

rous media. Journal of Soil Science 10: 79-82.

McAfee, M., Lindström, J. \& Johansson, W. 1989. Effects of presowing compaction on soil physical properties, soil atmosphere and growth of oats on a clay soil. Journal of Soil Science 40: 707-718.

Millington, R.J. 1959. Gas diffusion in porous media. Science 130: 100-102.

Moldrup, P., Olesen, T., Rolston, D.E. \& Yamaguchi, T. 1997. Modeling diffusion and reaction in soils: VII. Predicting gas and ion diffusivity in undisturbed and sieved soils. Soil Science 162: 632-640.

-, Olesen, T., Yamaguchi, T., Schønning, P. \& Rolston, D.E. 1999. Modeling diffusion and reaction in soils: VIII. Gas diffusion predicted from single-potential diffusivity or permeability measurements. Soil Science 162: 75-81.

Myhr, K. \& Njøs, A. 1983. Effects of tractor traffic, number of cuts and liming on yields and soil physical properties of in Norwegian grasslands. Meldinger fra Norges landbrukshøgskole 62, 1: 1-14.

-, Håland, Å. \& Nesheim, L. 1990. Verknad av våtkompostert og ubehandla blautgjødsel, og av jordpakking, på infiltrasjonen av vatn i dyrka jord (In Norwegian, English abstract). Norwegian Agricultural Research 4: 161-172.

Penman, H.L. 1940. Gas and vapour movement in the soil. Journal of Agricultural Science Cambridge 30: $570-581$.

Prins, W.H. \& Snijders, P.J.M. 1987. Negative effects of animal manure on grassland due to surface spreading and injection. In: Van der Meer, H.G. et al. (eds.) Animal Manure on Grassland and Fodder Crops. Fertilizer or Waste? Martinius Nijhoff Publishers. p. 119-135.

Rolston, D.E., Glauz, R.D., Grundmann, G.L. \& Louie,
D.T. 1991. Evaluation of an in situ method for measurement of gas diffusivity in surface soils. Soil Science Society of America Journal 55: 1536-1542.

Romell, L.G. 1922. Luftväxlingen i marken som ekologisk faktor (in Swedish and German). Reports of the Swedish Institute of Experimental Forestry 19: 125359.

SAS Institute Inc. 1987. SAS/STAT Guide for Personal Computers, Version 6 Edition. Cary, NC. 1028 p.

Soil Survey Staff 1975. Soil Taxonomy. A Basic System of Soil Classification for Making and Interpreting Soil Surveys. U.S. Department of Agriculture, Agriculture handbook $436.754 \mathrm{p}$.

Stepniewski, W. 1981. Oxygen diffusion and strength as relted to soil compaction. 2. Oxygen diffusion coefficient. Polish Journal of Soil Science 14: 3-13.

Stevens, R.J. \& Cornforth, I.S. 1974. The effect of pig slurry applied to a soil surface on the composition of the soil atmosphere. Journal of the Science of Food and Agriculture 25: 1263-1272.

Sveistrup, T.E. 1992. Morphological and physical properties of virgin and cultivated silty and sandy soils from Finnmark, Northern Norway. Norwegian Journal of Agricultural Sciences 6: 45-58.

-, Marcelino, \& Stoops, G. 1995. Effects of slurry application on the microstructure of the surface layers of soils from northern Norway. Norwegian Journal of Agricultural Sciences 9: 1-13.

Van der Meer, H.G., Thompson, R.B., Snijders, P.J.M. \& Geurink, J.H. 1987. Utilization of nitrogen from injected and surface-spread cattle slurry applied to grassland. In: Van der Meer, H.G. et al. (eds.). Animal Manure on Grassland and Fodder Crops. Fertilizer or Waste? Martinius Nijhoff Publishers. p. 4772. 
Haraldsen, T.K. Effects of cattle slurry and cultivation on air exchange

\title{
SELOSTUS
}

\section{Lietelannan levityksen ja viljelyn vaikutus maan ilmanvaihtoon Pohjois-Norjan hiekka- ja hiesumailla}

\author{
Trond Knapp Haraldsen \\ Planteforsk, Norja
}

Tutkimuksessa verrattiin viljelemättömän (ei koskaan kynnetty) ja viljellyn hiekka- ja hiesumaan huokoisuutta, diffuusionopeutta kaasuille ja ilmanläpäisykykyä. Maanäytteet kerättiin kahdelta paikkakunnalta Pohjois-Norjasta. Näytteistä, joissa maan luontainen rakenne oli säilytetty, määritettiin kaasun diffuusiokerroin ja ilmanläpäisykyky sekä ilman täyttämä huokostila neljässä eri veden potentiaalissa, joka vaihteli välillä $-1,5 \mathrm{kPa}$ ja $-60 \mathrm{kPa}$. Viljeltyjen maiden ilman täyttämä huokostila ja kaasun diffuusiokyky olivat pienempiä kuin viljelemättömien. Lietelannan levitys (50 $\mathrm{Mg} \mathrm{ha}^{-1}$ ) vähensi kaasun diffuusiokykyä ja muutti suhteellisen diffuusion riippuvuutta ilman täyttämästä huokostilasta sekä viljelemättömällä että viljellyllä hiekkamaalla ja viljelemättömällä hiesumaalla. Kaasunläpäisykyky sekä viljelemättömällä että viljellyllä hiesumaalla oli pieni ja suhteellinen diffuusiokyky jäi maan kosteuden vastatessa kenttäkapasiteettia pienemmäksi kuin raja, jonka alapuolella kaasun vaihto rajoittaa kasvin kehitystä. 